\title{
EMMANUEL DE WARESQUIEL, J'ai tant vu le soleil
}

\section{Michel Arrous}

\section{OpenEdition \\ Journals}

\section{Édition électronique}

URL : https://journals.openedition.org/studifrancesi/45184

DOI : $10.4000 /$ studifrancesi.45184

ISSN : 2421-5856

\section{Éditeur}

Rosenberg \& Sellier

\section{Édition imprimée}

Date de publication : 1 août 2021

Pagination : 381

ISSN : 0039-2944

\section{Référence électronique}

Michel Arrous, « emmanuel de waresquiel, J'ai tant vu le soleil », Studi Francesi [En ligne], 194 (LXV | II) | 2021, mis en ligne le 01 septembre 2021, consulté le 15 octobre 2022. URL : http://

journals.openedition.org/studifrancesi/45184; DOI : https://doi.org/10.4000/studifrancesi.45184

Ce document a été généré automatiquement le 15 octobre 2022.

\section{(c)}

Creative Commons - Attribution - Pas d'Utilisation Commerciale - Pas de Modification 4.0 International - CC BY-NC-ND 4.0

https://creativecommons.org/licenses/by-nc-nd/4.0/ 


\section{EMMANUEL DE WARESQUIEL, J'ai tant vu le soleil}

Michel Arrous

\section{RÉFÉRENCE}

EMMANUEl DE WARESQUIEL, J'ai tant vu le soleil, Paris, Gallimard, 2020, 118 pp.

Écrit d'une plume alerte, ce court essai témoigne de l'intime fréquentation de l'historien de la Restauration avec Stendhal. Bien que le titre, emprunté à une exclamation du consul inquiet un jour de 1834 à la perspective de mourir à Civitavecchia ou à Rome, suggère une méditation nostalgique, le propos privilégie une légèreté proche du laisser-aller stendhalien. Plutôt que d'un culte qui ne va pas sans une certaine complaisance à soi-même, on parlera d'affinité élective chez un lecteur séduit par «l'inépuisable fioriture de son moi» que Gracq décelait chez Stendhal. L'intérêt de cet exercice de parastendhalisme réside avant tout dans la qualité du lien qui unit le biographe de Talleyrand et de Fouché à l'auteur de la Chartreuse. Les stendhaliens rectifieront sans peine quelques confusions et approximations (pp. 31, 48, 62, $80,95,104)$, discuteront certaines affirmations comme le mépris des autres qui caractériserait Stendhal, sa totale incompréhension de l'œuvre de Chateaubriand, son désintérêt de la politique, et ils déploreront que la musique et la passion de l'opéra aient été oubliées. D'emblée, une formule s'impose que l'on vérifie à chaque page: «J'aime l'écrivain et donc j'aime l'homme». À la différence de Mérimée qui ne l'aurait regardé «que de profil», E. de Waresquiel a raison de déclarer que «pour le voir en entier, il faut l'aimer et le comprendre jusque dans ses contradictions». Tout en jouant au portrait chinois, l'auteur ponctue son parcours biographique de formules convaincantes: «Avec lui, on part forcément à la recherche de soi-même» (p. 19), ou, lors de l'enterrement de sa mère «Il ne voit rien d'autre que ce qui a la couleur de son âme» (p. 28), ou bien encore, à propos de la Pietragrua: «l'Italie a pris la forme de son 
visage» (p. 55). Citons aussi (p. 91) cette formule soufflée par Gracq: «Beyle n'est pas tombé avec l'Empire en 1814. Au contraire, la chute de Napoléon a été sa chance».

2 Donc, un "petit texte» au dire de l'auteur, mais sans rien qui pèse ou qui pose, une agréable invitation à entrer en Stendhalie. 